\title{
Energy cost of seed drying
}

\author{
Weerachet Jittanit*, George Srzednicki, Robert Driscoll \\ School of Chemical Sciences and Engineering, The University of New South Wales, Sydney, NSW 2052, \\ AUSTRALIA \\ *Corresponding Author-Tel: +66-86-895-8888, Fax: +66-2-562-5021
}

\begin{abstract}
In this work, the energy costs of drying corn, rice and wheat seeds between 3 drying options were compared. They consisted of 1) two-stage drying by using fluidised bed dryer (FBD) in the $1^{\text {st }}$ stage and in-store dryer (ISD) in the $2^{\text {nd }}$ stage, 2) single-stage drying by fixed bed dryer (FXD) and 3) two-stage drying by using FXD in the $1^{\text {st }}$ stage and ISD in the $2^{\text {nd }}$ stage. The drying conditions selected for comparison were proved to be safe for seed viability by the previous studies. The results showed that the drying options 2 and 3 consumed less energy than option 1 . However, the benefits from lower energy cost must be weighed against some advantages of using FBD. Furthermore, it appeared that running the burners of FXD and ISD for warming up the ambient air during humid weather condition could shorten drying time significantly with a little higher energy cost.
\end{abstract}

Keyword: Energy cost, Seed drying

\section{INTRODUCTION}

Generally, after harvesting the seeds must be dried in order to extend their storage life. When the seed is dried, normal metabolic changes, subcellular repair and turnover mechanisms become inactive. ${ }^{[1]}$ However when seeds are hydrated these mechanisms would be reactivated, but their efficiency depends on the damage accumulated.

Until now, there have been various drying methods to dry seeds. Leaving seeds to be dried in the field is a traditional and economical method for farmers; nevertheless, mechanical drying provides some significant advantages over in-field drying. For example, it enables the option of an earlier harvest, with probable benefits in yield and quality and reduces threat of weather damage. Due to their advantages, a number of artificial drying methods have been studied for drying seeds by the researchers. ${ }^{[2-4]}$

Generally, different drying techniques could result in the difference in the quality of dried seeds. Inappropriate drying condition can cause seed injury and vast economic loss. Moreover, different kinds of seeds seem to have dissimilar optimum drying conditions. ${ }^{[2-4]}$ The main factors, affecting the response of seed grain to hot air drying were previous history, species or variety, moisture content, exposure time and drier design. ${ }^{[2]}$ It was indicated that improper artificial drying could lower the seed germination, give rise to abnormal seedlings, affect on the permeability of the seedcoat, demolish enzymes, or harden the outer layers of seeds; so after the embryo imbibes water and swells, fractures and cracks develop. ${ }^{[3]}$

So far, the drying methods used in the seed drying researches could be divided into two main schemes consisting of single-stage and multi-stage drying. Due to the increasing concern about

* corresponding email: fagiwcj@ku.ac.th 
the energy conservation and the jumping energy cost, in this study the energy costs of drying were estimated and compared for corn, rice and wheat seeds between three drying options (one for single-stage drying and two for two-stage drying). The objective is to provide the information that the seed producers can apply for their economic decisions.

\section{[2] MATERIALS AND METHODS}

In this study, the energy costs of 3 seed drying options were estimated and compared. These options comprise with

Option1) Two-stage drying with the $1^{\text {st }}$ stage drying in FBD to dry seed from $25 \%$ wb to $18 \%$ wb and then the $2^{\text {nd }}$ stage drying in ISD to dry seed from $18 \% \mathrm{wb}$ to $\leq 14 \% \mathrm{wb}$.

Option2) Single-stage drying in FXD to dry seed from $25 \%$ wb to $\leq 14 \%$ wb.

Option3) Two-stage drying with the $1^{\text {st }}$ stage drying in FXD to dry seed from $25 \%$ wb to $18 \%$ wb and then the $2^{\text {nd }}$ stage drying in ISD to dry seed from $18 \% \mathrm{wb}$ to $\leq 14 \% \mathrm{wb}$.

The drying air conditions that were used for energy cost estimation for the FBD are presented in Table 1. They were proved to be safe for seed viability. ${ }^{[4]}$

TABLE 1 The drying conditions of the FBD used for energy cost estimation

\begin{tabular}{|c|c|c|c|c|}
\hline \multirow[b]{2}{*}{ Product } & \multicolumn{4}{|c|}{ Drying conditions } \\
\hline & $\begin{array}{c}\text { Drying air } \\
\text { temperature } \\
\left({ }^{\circ} \mathrm{C}\right)\end{array}$ & $\begin{array}{l}\text { Air velocity } \\
\qquad(\mathrm{m} / \mathrm{s})\end{array}$ & Bed depth (cm) & $\begin{array}{l}\text { Drying time } \\
\text { (min) }\end{array}$ \\
\hline Corn & 40 & \multirow{3}{*}{$2.8-3.0$} & \multirow{3}{*}{10} & 140 \\
\hline Rice & 40 & & & 60 \\
\hline Wheat & 60 & & & 15 \\
\hline
\end{tabular}

Unlike FBD, the FXD and ISD used the ambient air (temperature $\leq 43^{\circ} \mathrm{C}$ ) with the low to medium air velocity for drying seeds because these drying methods were recommended by a number of researchers. ${ }^{[5-6]}$ The drying times and the sizes of ISD and fixed bed dryer were estimated by using the existing drying simulation program (named "ISDryer") that had been developed by Driscoll and Srzednicki at the Department of Food Science and Technology, UNSW. The latest edition of this simulation program is version 6.01 edited in June 2006. In the program, there is a number of weather data that are used as an input for the simulation process. In this study, the drying simulation program was run using two weather files representing the wettest and the driest months of the existing weather records as detailed in Table 2. 
TABLE 2 The weather data used in the drying simulation for seeds of each crop

\begin{tabular}{|c|c|c|c|c|c|}
\hline Product & $\begin{array}{c}\text { Harvesting } \\
\text { season }\end{array}$ & Applied we ather data & $\begin{array}{c}\text { Existing } \\
\text { weather data }\end{array}$ & $\begin{array}{c}\text { Wettest } \\
\text { month }\end{array}$ & $\begin{array}{c}\text { Driest } \\
\text { month }\end{array}$ \\
\hline Corn & Aug-Oct & Bangkok, Thailand & Year 1965-1974 & Sep 1969 & Aug 1968 \\
\hline Rice & May-Sep & Bangkok, Thailand & Year 1965-1974 & Sep 1969 & June 1967 \\
\hline Wheat & Dec-Jan & Albany.WA. Australia & Year 19841994 & Jan 1989 & Jan 1986 \\
\hline
\end{tabular}

A number of assumptions were made for this cost analysis as following details.

\section{Assumptions}

1. Estimated operating time was 2 months a year (1,440 hours a year).

2. One Australian Dollar $\approx 30$ Baht (Thai currency).

3. Bed depths of seeds were $10 \mathrm{~cm}, 75 \mathrm{~cm}$ and 3 metres for FBD, FXD and ISD respectively.

4. The airflow rate used in the ISD and the FXD were 1 and $13 \mathrm{~m}^{3} / \mathrm{min}^{*} \mathrm{~m}^{3}$ seed respectively.

5. Heat energy source of all dryers was rice husk.

6. Approximate net heating value of rice husk $=11,704 \mathrm{KJ} / \mathrm{kg} \cdot{ }^{[7]}$

7. Cost of rice husk $=0.25$ Baht per $\mathrm{kg}$.

8. Electricity cost $=3$ Baht per unit.

9. Drying capacity and energy consumption of the ISD and the FXD were estimated by the ISD simulation program ("ISDryer" version 6.01).

10. Drying strategies in FXD and ISD were as follows:

10.1) In case of using burner, fan would be stopped if $\mathrm{RH}_{\text {ambient }}>95 \%$, burner would be turned on if $\mathrm{RH}>75 \%$ and temperature rise across burner $=5^{\circ} \mathrm{C}$.

10.2) In case of not using burner, fan would be stopped if $\mathrm{RH}_{\text {ambient }}>70 \%$.

11. The size and model of FBD was the same as in Soponronnarit's work. ${ }^{[8]}$

12. Ambient conditions used in the calculation for FBD were the average ambient conditions of the months used for drying simulation.

13. No recycled air in FBD.

14. Heat energy consumption of FBD was estimated by applying the experimental data in the Jittanit's study. ${ }^{[4]}$

15. Electrical energy consumption of FBD was estimated by applying the technical data of 5 tonnes/hour FBD in the brochure of Rice Engineering Supply Company Limited in Bangkok, Thailand. The 5 tonnes/hour FBD in this brochure should be the same or similar to the FBD in Soponronnarit's work. ${ }^{[8]}$

\section{[2] RESULTS AND DISCUSSION}

From the estimation, the sizes of FXD and ISD that were compatible with the drying capacity of FBD are summarised in Table 3. The calculation procedures can be seen in Jittanit's research. ${ }^{[4]}$ 
TABLE 3 Summary of the calculated sizes of FXD and ISD

\begin{tabular}{|c|c|c|c|c|c|c|c|c|}
\hline \multirow{3}{*}{ Dryer type } & \multirow{3}{*}{ Product } & \multirow{3}{*}{$\begin{array}{c}\text { Used } \\
\text { weather } \\
\text { data }\end{array}$} & \multicolumn{6}{|c|}{ Dryer Size $\left(\mathrm{m}^{3}\right)$} \\
\hline & & & \multicolumn{2}{|c|}{ Option 1} & \multicolumn{2}{|c|}{ Option 2} & \multicolumn{2}{|c|}{ Option 3} \\
\hline & & & $\begin{array}{c}\text { With } \\
\text { b urner }\end{array}$ & $\begin{array}{c}\text { No } \\
\text { b urner }\end{array}$ & $\begin{array}{c}\text { With } \\
\text { b urner }\end{array}$ & $\begin{array}{c}\text { No } \\
\text { b urner }\end{array}$ & $\begin{array}{c}\text { With } \\
\text { b urner }\end{array}$ & $\begin{array}{c}\text { No } \\
\text { b urner }\end{array}$ \\
\hline FXD & \multirow{4}{*}{ Corn } & \multirow{6}{*}{$\begin{array}{l}\text { Wettest } \\
\text { month }\end{array}$} & - & - & 4.2 & 56 & 2.4 & 37.4 \\
\hline ISD & & & 33.4 & 122.5 & - & - & 33.4 & 122.5 \\
\hline FXD & & & - & - & 6.2 & 93.5 & 4.1 & 83.6 \\
\hline ISD & & & 39.7 & 238 & - & - & 39.7 & 238 \\
\hline FXD & \multirow{2}{*}{ Wheat } & & - & - & 4.8 & 48.8 & 25.5 & 25.5 \\
\hline ISD & & & 177.3 & 255 & - & - & 177.3 & 255 \\
\hline FXD & \multirow{2}{*}{ Corn } & \multirow{6}{*}{$\begin{array}{l}\text { Driest } \\
\text { month }\end{array}$} & - & - & 3.2 & 15 & 1.8 & 7.9 \\
\hline ISD & & & 21 & 59.5 & - & - & 21 & 59.5 \\
\hline FXD & \multirow{2}{*}{ Rice } & & - & - & 5 & 19.3 & 3.3 & 12.5 \\
\hline ISD & & & 28 & 81 & - & - & 28 & 81 \\
\hline FXD & \multirow{2}{*}{ Wheat } & & - & - & 54.9 & 88.7 & 21 & 49.9 \\
\hline ISD & & & 144 & 199.5 & - & - & 144 & 199.5 \\
\hline
\end{tabular}

The results of cost analysis are shown in Table 4 to 9 ( 2 tables for seeds of each crop). In the tables, due to the fact that Thailand is one of the major producers of food grains in the world, the costs were presented in the Thai currency Baht. However, the costs shown in the tables for wheat were also calculated in Australian Dollar (AUD) and placed in the brackets because Australia is an important wheat exporter. 
TABLE 4 The energy costs of drying corn seeds in the wettest month

\begin{tabular}{|c|c|c|c|c|c|c|}
\hline \multirow[b]{2}{*}{ Description } & \multicolumn{2}{|c|}{ Optionl } & \multicolumn{2}{|c|}{ Option2 } & \multicolumn{2}{|c|}{ Option 3 } \\
\hline & With Burner & $\begin{array}{l}\text { Without } \\
\text { Burner }\end{array}$ & With Burner & $\begin{array}{l}\text { Without } \\
\text { Burner }\end{array}$ & With Burner & $\begin{array}{l}\text { Without } \\
\text { Burner }\end{array}$ \\
\hline $\begin{array}{l}\text { 1) Drying capacity } \\
\text { (tyear) }\end{array}$ & 65 & 65 & 65 & 65 & 65 & 65 \\
\hline 2) Drying scheme & $\begin{array}{l}1^{s t} \text { stage in } \\
\text { FBD and } \\
2^{\text {sel }} \text { stage in } \\
\text { ISD for } 560 \mathrm{~h}\end{array}$ & $\begin{array}{l}1^{\text {tt }} \text { stage in } \\
\text { FBD and } 2^{\text {vil }} \\
\text { stage in ISD } \\
\text { for } 2,100 \mathrm{~h}\end{array}$ & $\begin{array}{l}\text { Single stage } \\
\text { in FXD } \\
\text { for } 70 \mathrm{~h}\end{array}$ & $\begin{array}{c}\text { Single stage } \\
\text { in FXD for } \\
960 \mathrm{~h}\end{array}$ & $\begin{array}{c}1^{\text {st }} \text { stage in } \\
\text { FXD for } 41 \mathrm{~h} \\
\text { and } \\
2^{\text {sul }} \text { stage in } \\
\text { ISD for } 560 \mathrm{~h}\end{array}$ & $\begin{array}{c}1^{\text {st }} \text { stage in } \\
\text { FXD for } 640 \\
\mathrm{~h} \text { and } 2^{\text {sl }} \\
\text { stage in ISD } \\
\text { for } 2,100 \mathrm{~h}\end{array}$ \\
\hline \multicolumn{7}{|l|}{$\begin{array}{l}\text { 3) Energy cost } \\
\text { estimation }\end{array}$} \\
\hline \multicolumn{7}{|l|}{ 3.1) $1^{\text {st }}$ stage dryer } \\
\hline $\begin{array}{l}\text { 3.1.1) Electrical } \\
\text { energy cost }\end{array}$ & 58,804 & 58,804 & 1,308 & 1,266 & 727 & 711 \\
\hline $\begin{array}{l}\text { 3.1.2) Heat energy } \\
\text { cost }\end{array}$ & 9,642 & 9,642 & 508 & - & 260 & - \\
\hline \multicolumn{7}{|l|}{ 3.2) ISD } \\
\hline $\begin{array}{l}\text { 3.2.1) Electrical } \\
\text { energy cost }\end{array}$ & 557 & 513 & - & - & 557 & 513 \\
\hline $\begin{array}{l}\text { 3.2.2) Heat energy } \\
\text { cost }\end{array}$ & 209 & - & - & - & 209 & - \\
\hline $\begin{array}{l}\text { Net annual energy } \\
\text { cost }\end{array}$ & 69,213 & 68,959 & 1,816 & 1,266 & 3,194 & 1,224 \\
\hline $\begin{array}{l}\text { Energy cost per } \\
\text { lggend }\end{array}$ & 1.065 & 1.061 & 0.028 & 0.019 & 0.049 & 0.019 \\
\hline
\end{tabular}

TABLE 5 The energy costs of drying corn seeds in the driest month

\begin{tabular}{|c|c|c|c|c|c|c|}
\hline \multirow[b]{2}{*}{ Description } & \multicolumn{2}{|c|}{ Optionl } & \multicolumn{2}{|c|}{ Option2 } & \multicolumn{2}{|c|}{ Option 3 } \\
\hline & With Burner & $\begin{array}{l}\text { Without } \\
\text { Burner }\end{array}$ & With Burner & $\begin{array}{l}\text { Without } \\
\text { Burner }\end{array}$ & With Burner & $\begin{array}{l}\text { Without } \\
\text { Burner }\end{array}$ \\
\hline $\begin{array}{l}\text { 1) Drying capacity } \\
\text { (tyear) }\end{array}$ & 65 & 65 & 65 & 65 & 65 & 65 \\
\hline 2) Drying scheme & $\begin{array}{l}1^{\text {st }} \text { stage in } \\
\text { FBD and } \\
2^{\text {ml }} \text { stage in } \\
\text { ISD for } 360 \mathrm{~h}\end{array}$ & $\begin{array}{l}1^{\text {st }} \text { stage in } \\
\text { FBD and } 2^{\text {thl }} \\
\text { stage in ISD } \\
\text { for } 1,020 \mathrm{~h}\end{array}$ & $\begin{array}{l}\text { Single stage } \\
\text { in FXD } \\
\text { for } 56 \mathrm{~h}\end{array}$ & $\begin{array}{c}\text { Single stage } \\
\text { in FXD for } \\
255 \mathrm{~h}\end{array}$ & $\begin{array}{c}1^{\text {st stage in }} \\
\text { FXD for } 31 \mathrm{~h} \\
\text { and } \\
2^{\text {sul }} \text { stage in } \\
\text { ISD for } 360 \mathrm{~h}\end{array}$ & $\begin{array}{c}1^{\text {st }} \text { stage in } \\
\text { FXD for } 136 \\
\mathrm{~h} \text { and } 2^{\text {tul }} \\
\text { stage in ISD } \\
\text { for } 1,020 \mathrm{~h}\end{array}$ \\
\hline \multicolumn{7}{|l|}{$\begin{array}{l}\text { 3) Energy cost } \\
\text { estimation }\end{array}$} \\
\hline \multicolumn{7}{|l|}{ 3.1) $1^{\text {st }}$ stage dryer } \\
\hline $\begin{array}{l}\text { 3.1.1) Electrical } \\
\text { energy cost }\end{array}$ & 58,804 & 58,804 & 1,095 & 1,223 & 613 & 677 \\
\hline $\begin{array}{l}\text { 3.1.2) Heat energy } \\
\text { cost }\end{array}$ & 9,395 & 9,395 & 308 & - & 179 & - \\
\hline \multicolumn{7}{|l|}{ 3.2) ISD } \\
\hline $\begin{array}{l}\text { 3.2.1) Electrical } \\
\text { energy cost }\end{array}$ & 541 & 516 & - & - & 541 & 516 \\
\hline $\begin{array}{l}\text { 3.2.2) Heat energy } \\
\text { cost } \\
\end{array}$ & 134 & - & - & - & 134 & - \\
\hline $\begin{array}{l}\text { Net annual energy } \\
\text { cost }\end{array}$ & 68,874 & 68,715 & 1,403 & 1,223 & 2,907 & 1,192 \\
\hline Energy cost per & 1.060 & 1.057 & 0.022 & 0.019 & 0.045 & 0.018 \\
\hline
\end{tabular}


TABLE 6 The energy costs of drying rice seeds in the wettest month

\begin{tabular}{|c|c|c|c|c|c|c|}
\hline \multirow[b]{2}{*}{ Description } & \multicolumn{2}{|c|}{ Optionl } & \multicolumn{2}{|c|}{ Option2 } & \multicolumn{2}{|c|}{ Option 3} \\
\hline & With Burner & $\begin{array}{l}\text { Without } \\
\text { Burner }\end{array}$ & With Burner & $\begin{array}{l}\text { Without } \\
\text { Burner }\end{array}$ & With Burner & $\begin{array}{c}\text { Without } \\
\text { Burner }\end{array}$ \\
\hline $\begin{array}{l}\text { 1) Drying capacity } \\
\text { (tyear) }\end{array}$ & 120 & 120 & 120 & 120 & 120 & 120 \\
\hline 2) Drying scheme & $\begin{array}{l}1^{\text {st }} \text { stage in } \\
\text { FBD and } \\
2^{\text {sll stage in }} \\
\text { ISD for } 280 \mathrm{~h}\end{array}$ & $\begin{array}{l}1^{\text {st }} \text { stage in } \\
\text { FBD and } 2^{\text {ml }} \\
\text { stage in ISD } \\
\text { for } 1,680 \mathrm{~h}\end{array}$ & $\begin{array}{l}\text { Single stage } \\
\text { in FXD for } \\
44 \mathrm{~h}\end{array}$ & $\begin{array}{c}\text { Single stage } \\
\text { in FXD for } \\
660 \mathrm{~h}\end{array}$ & $\begin{array}{c}1^{\text {st }} \text { stage in } \\
\text { FXD for } 29 \mathrm{~h} \\
\text { and } \\
2^{\text {wll }} \text { stage in } \\
\text { ISD for } 280 \mathrm{~h}\end{array}$ & $\begin{array}{c}1^{\text {st }} \text { stage in } \\
\text { FXD for } 590 \\
\mathrm{~h} \text { and } 2^{\text {whl }} \\
\text { stage in ISD } \\
\text { for } 1,680 \mathrm{~h}\end{array}$ \\
\hline \multicolumn{7}{|l|}{$\begin{array}{l}\text { 3) Energy cost } \\
\text { estimation }\end{array}$} \\
\hline \multicolumn{7}{|l|}{ 3.1) $1^{\text {st }}$ stage dryer } \\
\hline $\begin{array}{l}\text { 3.1.1) Electrical } \\
\text { energy cost }\end{array}$ & 58,804 & 58,804 & 4,526 & 4,435 & 2,994 & 2,800 \\
\hline $\begin{array}{l}\text { 3.1.2) Heat energy } \\
\text { cost }\end{array}$ & 7,792 & 7,792 & 714 & - & 425 & - \\
\hline \multicolumn{7}{|l|}{ 3.2) ISD } \\
\hline $\begin{array}{l}\text { 3.2.1) Electrical } \\
\text { energy cost }\end{array}$ & 1816 & 1797 & - & - & 1,816 & 1,797 \\
\hline $\begin{array}{l}\text { 3.2.2) Heat energy } \\
\text { cost }\end{array}$ & 292 & - & - & - & 292 & - \\
\hline $\begin{array}{l}\text { Net annual energy } \\
\text { cost }\end{array}$ & 68,703 & 68,393 & 5,240 & 4,435 & 6,967 & 4,597 \\
\hline $\begin{array}{l}\text { Energy cost per } \\
\text { kg }_{\text {gend }}\end{array}$ & 0.573 & 0.570 & 0.044 & 0.037 & 0.058 & 0.038 \\
\hline
\end{tabular}

TABLE 7 The energy costs of drying rice seeds in the driest month

\begin{tabular}{|c|c|c|c|c|c|c|}
\hline \multirow[b]{2}{*}{ Description } & \multicolumn{2}{|c|}{ Optionl } & \multicolumn{2}{|c|}{ Option2 } & \multicolumn{2}{|c|}{ Option 3 } \\
\hline & With Burner & $\begin{array}{l}\text { Without } \\
\text { Burner }\end{array}$ & With Burner & $\begin{array}{l}\text { Without } \\
\text { Burner }\end{array}$ & With Burner & $\begin{array}{l}\text { Without } \\
\text { Burner }\end{array}$ \\
\hline $\begin{array}{l}\text { 1) Drying capacity } \\
\text { (t/year) }\end{array}$ & 120 & 120 & 120 & 120 & 120 & 120 \\
\hline 2) Drying scheme & $\begin{array}{c}1^{\text {st }} \text { stage in } \\
\text { FBD and } \\
2^{\text {nl }} \text { stage in } \\
\text { ISD for } 198 \mathrm{~h}\end{array}$ & $\begin{array}{l}1^{\text {st }} \text { stage in } \\
\text { FBD and } \\
2^{\text {sul }} \text { stage in } \\
\text { ISD for } 570 \mathrm{~h}\end{array}$ & $\begin{array}{l}\text { Single stage } \\
\text { in FXD } \\
\text { for } 35 \mathrm{~h}\end{array}$ & $\begin{array}{l}\text { Single stage } \\
\text { in FXD for } \\
136 \mathrm{~h}\end{array}$ & $\begin{array}{c}1^{\text {st }} \text { stage in } \\
\text { FXD for } 23 \mathrm{~h} \\
\text { and } \\
2^{\text {wal }} \text { stage in } \\
\text { ISD for } 198 \mathrm{~h}\end{array}$ & $\begin{array}{c}1^{\text {st }} \text { stage in } \\
\text { FXD for } 88 \mathrm{~h} \\
\text { and } \\
2^{\text {wil }} \text { stage in } \\
\text { ISD for } 570 \mathrm{~h}\end{array}$ \\
\hline \multicolumn{7}{|l|}{$\begin{array}{l}\text { 3) Energy cost } \\
\text { estimation }\end{array}$} \\
\hline \multicolumn{7}{|l|}{ 3.1) $1^{\text {st }}$ stage dryer } \\
\hline $\begin{array}{l}\text { 3.1.1) Electrical } \\
\text { energy cost }\end{array}$ & 58,804 & 58,804 & 3,863 & 4,533 & 2,573 & 2,882 \\
\hline $\begin{array}{l}\text { 3.1.2) Heat energy } \\
\text { cost }\end{array}$ & 7,192 & 7,192 & 538 & - & 303 & - \\
\hline \multicolumn{7}{|l|}{ 3.2) ISD } \\
\hline $\begin{array}{l}\text { 3.2.1) Electrical } \\
\text { energy cost }\end{array}$ & 1,741 & 1,667 & - & - & 1,741 & 1,667 \\
\hline $\begin{array}{l}\text { 3.2.2) Heat energy } \\
\text { cost }\end{array}$ & 189 & - & - & - & 189 & - \\
\hline $\begin{array}{l}\text { Net annual energy } \\
\text { cost }\end{array}$ & 67,926 & 67,664 & 4,401 & 4,533 & 6,246 & 4,549 \\
\hline Energy cost per & 0.566 & 0.564 & 0.037 & 0.038 & 0.052 & 0.038 \\
\hline
\end{tabular}


TABLE 8 The energy costs of drying wheat seeds in the wettest month

\begin{tabular}{|c|c|c|c|c|c|c|}
\hline \multirow[b]{2}{*}{ Description } & \multicolumn{2}{|c|}{ Optionl } & \multicolumn{2}{|c|}{ Option2 } & \multicolumn{2}{|c|}{ Option 3} \\
\hline & With Burner & $\begin{array}{l}\text { Without } \\
\text { Burner }\end{array}$ & With Burner & $\begin{array}{l}\text { Without } \\
\text { Burner }\end{array}$ & With Burner & $\begin{array}{l}\text { Without } \\
\text { Burner }\end{array}$ \\
\hline $\begin{array}{l}\text { 1) Drying capacity } \\
\text { (t/year) }\end{array}$ & 600 & 600 & 600 & 600 & 600 & 600 \\
\hline 2) Drying scheme & $\begin{array}{l}1^{s t} \text { stage in } \\
\text { FBD and } \\
2^{\text {wel }} \text { stage in } \\
\text { ISD for } 320 \mathrm{~h}\end{array}$ & $\begin{array}{l}1^{s \dagger} \text { stage in } \\
\text { FBD and } \\
2^{\text {wll }} \text { stage in } \\
\text { ISD for } 460 \mathrm{~h}\end{array}$ & $\begin{array}{l}\text { Single stage } \\
\text { in FXD } \\
\text { for } 99 \mathrm{~h}\end{array}$ & $\begin{array}{c}\text { Single stage } \\
\text { in FXD for } \\
160 \mathrm{~h}\end{array}$ & $\begin{array}{c}1^{\text {st stage in }} \\
\text { FXD for } 46 \mathrm{~h} \\
\text { and } \\
2^{\text {sul }} \text { stage in } \\
\text { ISD for } 320 \mathrm{~h}\end{array}$ & $\begin{array}{c}1^{\text {st } s t a g e ~ i n ~} \\
\text { FXD for } 46 \mathrm{~h} \\
\text { and } \\
2^{\text {sul }} \text { stage in } \\
\text { ISD for } 460 \mathrm{~h}\end{array}$ \\
\hline \multicolumn{7}{|l|}{$\begin{array}{l}\text { 3) Energy cost } \\
\text { estimation }\end{array}$} \\
\hline \multicolumn{7}{|l|}{ 3.1) $1^{s t}$ stage dryer } \\
\hline $\begin{array}{l}\text { 3.1.1) Electrical } \\
\text { energy cost }\end{array}$ & $\begin{array}{l}58,804 \\
(1,960)\end{array}$ & $\begin{array}{l}58,804 \\
(1,960)\end{array}$ & $\begin{array}{l}41,978 \\
(1,399)\end{array}$ & $\begin{array}{l}37,957 \\
(1,265)\end{array}$ & $20,088(670)$ & $20,088(670)$ \\
\hline $\begin{array}{l}\text { 3.1.2) Heat energy } \\
\text { cost }\end{array}$ & $\begin{array}{l}33,243 \\
(1,108)\end{array}$ & $\begin{array}{l}33,243 \\
(1,108)\end{array}$ & $2,922(97)$ & 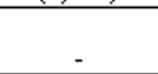 & 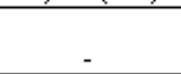 & 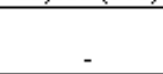 \\
\hline \multicolumn{7}{|l|}{ 3.2) ISD } \\
\hline $\begin{array}{l}\text { 3.2.1) Electrical } \\
\text { energy cost }\end{array}$ & $9,667(322)$ & $8,271(276)$ & - & - & $9,667(322)$ & $8,271(276)$ \\
\hline $\begin{array}{l}\text { 3.2.2) Heat energy } \\
\text { cost }\end{array}$ & $659(22)$ & (2) & - & - & $659(22)$ & 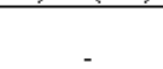 \\
\hline $\begin{array}{l}\text { Net annual energy } \\
\text { cost }\end{array}$ & $\begin{array}{l}102,373 \\
(3,412)\end{array}$ & $\begin{array}{l}100,318 \\
(3,344)\end{array}$ & $\begin{array}{l}44,900 \\
(1,497)\end{array}$ & $\begin{array}{l}37,957 \\
(1,265)\end{array}$ & $\begin{array}{l}31,854 \\
(2,454)\end{array}$ & $28,359(945)$ \\
\hline Energy cost per & $\begin{array}{c}0.171 \\
(0.0057)\end{array}$ & $\begin{array}{c}0.167 \\
(0.0056)\end{array}$ & $\begin{array}{c}0.075 \\
(0.0025)\end{array}$ & $\begin{array}{c}0.063 \\
(0.0021)\end{array}$ & $\begin{array}{c}0.053 \\
(0.0041)\end{array}$ & $\begin{array}{c}0.047 \\
(0.0016)\end{array}$ \\
\hline
\end{tabular}

TABLE 9 The energy costs of drying wheat seeds in the driest month

\begin{tabular}{|c|c|c|c|c|c|c|}
\hline \multirow[b]{2}{*}{ Description } & \multicolumn{2}{|c|}{ Optionl } & \multicolumn{2}{|c|}{ Option2 } & \multicolumn{2}{|c|}{ Option 3 } \\
\hline & With Burner & $\begin{array}{l}\text { Wizthout } \\
\text { Burner }\end{array}$ & With Burner & $\begin{array}{l}\text { Without } \\
\text { Burner }\end{array}$ & With Burner & $\begin{array}{l}\text { Without } \\
\text { Burner }\end{array}$ \\
\hline $\begin{array}{l}\text { 1) Drying capacity } \\
\text { (t'year) }\end{array}$ & 600 & 600 & 600 & 600 & 600 & 600 \\
\hline 2) Drying scheme & $\begin{array}{l}1^{\text {st }} \text { stage in } \\
\text { FBD and } \\
2^{\text {wel }} \text { stage in } \\
\text { ISD for } 260 \mathrm{~h}\end{array}$ & $\begin{array}{l}1^{\text {st }} \text { stage in } \\
\text { FBD and } \\
2^{\text {nel }} \text { stage in } \\
\text { ISD for } 360 \mathrm{~h}\end{array}$ & $\begin{array}{l}\text { Single stage } \\
\text { in FXD } \\
\text { for } 87 \mathrm{~h}\end{array}$ & $\begin{array}{l}\text { Single stage } \\
\text { in FXD } \\
\text { for } 88 \mathrm{~h}\end{array}$ & $\begin{array}{l}1^{\text {st }} \text { stage in } \\
\text { FXD for } 38 \mathrm{~h} \\
\text { and } \\
2^{\text {nel }} \text { stage in } \\
\text { ISD for } 260 \mathrm{~h}\end{array}$ & $\begin{array}{c}1^{\text {st }} \text { stage in } \\
\text { FXD for } 90 \mathrm{~h} \\
\text { and } \\
2^{\text {wil }} \text { stage in } \\
\text { ISD for } 360 \mathrm{~h}\end{array}$ \\
\hline $\begin{array}{l}\text { 3) Energy cost } \\
\text { estimation }\end{array}$ & & & & & & \\
\hline 3.1) $1^{\text {st }}$ stage dryer & & & & & & \\
\hline $\begin{array}{l}\text { 3.1.1) Electrical } \\
\text { energy cost }\end{array}$ & $\begin{array}{l}58,804 \\
(1,960)\end{array}$ & $\begin{array}{l}58,804 \\
(1,960)\end{array}$ & $\begin{array}{l}37,380 \\
(1,246)\end{array}$ & $\begin{array}{l}32,341 \\
(1,078)\end{array}$ & $16,655(555)$ & $15,576(519)$ \\
\hline $\begin{array}{l}\text { 3.1.2) Heat energy } \\
\text { cost }\end{array}$ & $\begin{array}{l}32,452 \\
(1,082)\end{array}$ & $\begin{array}{l}32,452 \\
(1,082)\end{array}$ & $813(27)$ & - & $1,234(41)$ & 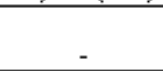 \\
\hline 3.2) ISD & & & & & & \\
\hline $\begin{array}{l}\text { 3.2.1) Electrical } \\
\text { energy cost }\end{array}$ & $8,962(299)$ & $8,642(288)$ & - & - & $8,962(299)$ & $8,642(288)$ \\
\hline $\begin{array}{l}\text { 3.2.2) Heat energy } \\
\text { cost }\end{array}$ & 331 (11) & - & - & - & 331 (11) & - \\
\hline $\begin{array}{l}\text { Net amnual energy } \\
\text { cost }\end{array}$ & $\begin{array}{l}100,549 \\
(3,352)\end{array}$ & $\begin{array}{l}99,898 \\
(3,330)\end{array}$ & $\begin{array}{l}38,194 \\
(1,273)\end{array}$ & $\begin{array}{l}32,341 \\
(1,078)\end{array}$ & $\begin{array}{l}28,623 \\
(2,346)\end{array}$ & $24,218(807)$ \\
\hline $\begin{array}{l}\text { Energy cost per } \\
\text { kg }_{\text {gand }}\end{array}$ & $\begin{array}{c}0.168 \\
(0.0056)\end{array}$ & $\begin{array}{c}0.166 \\
(0.0055)\end{array}$ & $\begin{array}{c}0.064 \\
(0.0021)\end{array}$ & $\begin{array}{c}0.054 \\
(0.0018)\end{array}$ & $\begin{array}{c}0.048 \\
(0.0039)\end{array}$ & $\begin{array}{c}0.040 \\
(0.0013)\end{array}$ \\
\hline
\end{tabular}

According to the results, it appears that option 2 and 3 resulted in lower energy cost than option 1. Moreover, it is worthwhile to use the burner when the weather is wet because the running of burner can shorten the drying time significantly with a little higher energy cost. As a consequence, the risk of infestation by microorganisms or insects in the seed lot caused by long time exposure to the high moisture air is reduced. 
Due to the information provided by some studies, the market price of seeds is much more expensive than that of food grain for each crop. ${ }^{[9-11]}$ So, although option 1 resulted in higher energy cost, it is worthwhile paying a higher energy cost if it can reduce the risk of downgrading the grains from seed to food grade. Generally, the advantages of FBD are uniformity of product caused by the good mixing and flexibility in terms of the minimum required amount of product. Besides, the FBD could be designed to be mobile type and due to its high drying rate, the FBD could be used directly in the field to dry seeds immediately after harvest and to maintain the quality of seeds under severe weather conditions. Therefore, the lower energy cost of option 2 and 3 must be weighed with the higher quality of the seeds in term of uniformity and lower risks of mould growth and chemical reactions due to fast drying in the $1^{\text {st }}$ stage provided by option 1 .

Another issue is that the large amount of dried product required the storage silo. Two-stage drying system using an ISD as the $2^{\text {nd }}$ stage dryer might be attractive because ISD could be used as a storage silo. In contrast, a single-stage drying system using a FXD would require an additional investment for storage silo.

\section{CONCLUSIONS}

The energy cost analysis showed that single-stage drying in a FXD and two-stage drying by FXD and ISD using ambient air together with burner consumed less energy than two-stage drying using FBD and ISD. Nevertheless, the benefits from lower energy cost must be weighed against faster drying rates, flexibility, possibility of a portable design, and product uniformity offered by the FBD.

Eventually, the recommendation is that in the future, the research should be expanded to other kinds of seeds especially higher value crops such as soybean and peanut because the twostage drying system might be more attractive for drying these kinds of seeds.

\section{ACKNOWLEDGEMENTS}

\section{THE AUTHORS WOULD LIKE TO PRESENT THE APPRECIATION TO ACIAR FOR THE PROJECT GRANT.}

\section{REFERENCES}

1. Roberts, E.H., Physiology of ageing and its application to drying and storage, Seed Sci. \& Technol., 1981, 9, 359-372.

2. Hebblethwaite, P.D.; Seed Production; Butterworths, London, 1980; 314-315, 372-376.

3. Thomson, J.R.; Harvesting and Drying; An Introduction to Seed Technology; Leonard Hill, Thompson Litho Ltd., East Killbride, Scotland, 1979; 77-91.

4. Jittanit, W., Modelling of seed drying using a two-stage drying concept, PhD Thesis, 2007, The University of New South Wales, Sydney, Australia.

5. Soponronnarit, S.; Drying of grain and some kinds of food; King Mongkut's University of Technology Thonburi, Thailand, 1997; $7^{\text {th }}$ ed. (Thai version); 217.

6. McDonald, M.B. and Copeland, L.O.; Seed Production: Principles and Practices; Chapman \& Hall, New York, 1997. 
7. Mao, J.X., The energy structure and the technology of co-firing biomass and coal in China, Int. J. Power Energy Syst., 2004, 24(3), Digital Object Identifier: 10.2316/Journal 203.2004.3.203-3414.

8. Soponronnarit, S., Rordprapat, P. and Wetchacama, S., Mobile fluidized bed paddy dryer, Drying Technol., 1998, 16(7), 1501-1513.

9. CIMMYT (International Maize and Wheat Improvement Center); Maize production in drought-stressed environments: technical options and research resource allocation, Part 3; Selected Maize Statistics; CIMMYT, Mexico, 1999; 51.

10. Brees, M.; Corn and irrigated corn cost-return budgets for Northern, Central and Southwest Missouri; Farm Management Guide: FBM-0101; College of Agricultural, Food and Natural Resources, University of Missouri, October 2003.

11. Brees, M.; Wheat and double crop soybean budgets for Northern, Central and Southwest Missouri; Farm Management Guide: FBM-0301; College of Agricultural, Food and Natural Resources, University of Missouri, October 2003. 